\title{
Rheumatoid lymphadenopathy: a morphological and immunohistochemical study
}

\author{
G M Kondratowicz, D P M Symmons, P A Bacon, R A K Mageed, E L Jones
}

\begin{abstract}
Sixteen lymph nodes from 14 patients with rheumatoid arthritis were examined immunohistochemically and morphometrically and compared with 10 control nodes showing follicular hyperplasia from patients without rheumatoid disease. Frozen material was available from nine patients and all controls. The nodes from patients with rheumatoid arthritis seemed to share characteristic features. The most striking of these was follicular hyperplasia in which the germinal centres, in spite of being quite large, showed relatively sparse proliferative activity. The nodes often showed infiltration of germinal centres by $\mathrm{CD8}$ positive $T$ lymphocytes and contained fewer IL.2R positive cells in the paracortex than controls. These and other features may have some correlation with disease activity.

Lymphadenopathy in rheumatoid arthritis may not just be a manifestation of joint inflammation but an active component of this multisystem disease and may reflect a widespread immunological abnormality.
\end{abstract}

Lymphadenopathy is common in rheumatoid arthritis, affecting up to $75 \%$ of patients at some stage of their disease. ${ }^{1}$ It may occur in nodes draining an inflamed joint but can also be generalised. ${ }^{2}$ A proportion of such patients undergo lymph node biopsy to exclude malignant disease, particularly lymphoma, which is significantly increased in incidence in rheumatoid arthritis. ${ }^{34}$

The histological features of rheumatoid lym-

The Medical School, University of Birmigham Department of Pathology

G M Kondratowicz

E L Jones

Department of

Rheumatology

D P M Symmons

P A Bacon

Department of

Immunology

R A K Mageed

Correspondence to:

Dr G M Kondratowicz,

Department of Pathology,

The Medical School,

The Medical School,

University of Birmingh

Birmingham

Accepted for publication

6 September 1989 phadenopathy have been described by several authors ${ }^{125-7}$ who have emphasised the striking but non-specific feature of follicular hyperplasia that is often accompanied by sinus histiocytosis. Occasional cases have been misdiagnosed as follicular lymphoma and this may still occur if the pathologist is unaware of the patient's arthritis. ${ }^{8}$

A recent study used immunohistochemistry to examine rheumatoid lymphadenopathy but was limited by a lack of frozen material so that $T$ cell subsets in particular could not be examined. ${ }^{8}$

The aims of this study were to reassess the alleged non-specific features of rheumatoid lymphadenopathy using immunohistochemical and morphometric techniques on frozen as well as paraffin wax embedded tissues. Unlike previous studies it was considered important to compare the findings with those in a control group of nodes from patients without rheumatoid disease showing non-specific follicular hyperplasia in the hope that further light might be shed on any more widespread immunological abnormalities which might be reflected in the lymph nodes. Correlation of the lymph node appearances with disease activity and other clinical features was also attempted.

\section{Patients and methods}

Lymph nodes from 14 patients with rheumatoid arthritis, all fulfilling the American Rheumatism Association criteria for rheumatoid arthritis, ${ }^{9}$ were retrieved from the files of the department of pathology. All the patients had undergone lymph node biopsy to exclude malignancy. Two patients were biopsied twice. Frozen tissue was available from nine patients -11 women and three men, the mean age of whom was 64 years (range 31-82 years). All the nodes had been removed from the neck or the axilla. The clinical details are summarised in table 1.

Ten control reactive nodes reported as showing follicular hyperplasia with non-specific features, for which frozen tissue was available, were selected at random. These were from six men and four women, the mean age of whom was 28.4 years (range 16-53 years). Most had no obvious cause for the lymphadenopathy and were well on follow up. One patient had a history of malignant lymphoma and had had an episode of herpes zoster infection just before biopsy which may have been responsible for the node enlargement (control case 10). One patient (control case 2), an East African with a history of syphilis and malaria, may in view of the decreased helper:suppressor (CD4 positive:CD8 positive) cell ratio in his lymph nodes, have had AIDS related lymphadenopathy. He returned to Africa and so was lost to follow up. Six nodes were removed from the neck, three from the inguinal region, and one from the axilla.

\section{HISTOLOGY}

Paraffin wax sections $5 \mu \mathrm{m}$ thick were cut and stained with haematoxylin and eosin, Congo red, Perls's stain, periodic acid Schiff, and haematoxylin van Gieson. A Masson fontana and a reticulin stain were done as necessary.

The following features were noted: regularity and fusion of germinal centres; extension of germinal centres into the medulla and outside the capsule of the node; thickening of the node capsule; prominence of sinuses; and 
Table 1 Patient details

\begin{tabular}{|c|c|c|c|c|c|c|c|}
\hline Case No & Age & $/ \operatorname{sex}$ & $\begin{array}{l}\text { Disease } \\
\text { duration (yrs) }\end{array}$ & $\begin{array}{l}\text { Rheumatoid } \\
\text { factor (titre) }\end{array}$ & $\begin{array}{l}\text { ESR } \\
\mathrm{mm} / \text { hour }\end{array}$ & $\begin{array}{l}\text { Maximum diameter of } \\
\text { largest node }(\mathrm{cm})\end{array}$ & $\begin{array}{l}\text { Other features/drug treatment } \\
\text { at time of biopsy }\end{array}$ \\
\hline 1 & 63 & $\mathbf{M}$ & 9 & $1 / 4096$ & 130 & $1.9 / 1 \cdot 4$ & $\begin{array}{l}\text { Sjögren's syndrome, Raynaud's } \\
\text { phenomenon; salazopyrin }\end{array}$ \\
\hline $\begin{array}{l}2 \\
3 \\
4 \\
5\end{array}$ & $\begin{array}{l}54 \\
56 \\
70 \\
66\end{array}$ & $\begin{array}{l}\mathbf{M} \\
\mathbf{F} \\
\mathbf{F} \\
\mathbf{F}\end{array}$ & $\begin{array}{r}15 \\
6 \\
2 \\
7\end{array}$ & $\begin{array}{l}1 / 4096 \\
1 / 512 \\
\text { Negative } \\
1 / 128\end{array}$ & $\begin{array}{r}100 \\
62 \\
10 \\
25\end{array}$ & $\begin{array}{l}1 \cdot 1 \\
1 \cdot 4 \\
1 \cdot 3 \\
0 \cdot 9\end{array}$ & $\begin{array}{l}\text { Nodules, asthma; steroids } \\
\text { Asthma; salazopyrin, gold } \\
\text { Non-steroidal anti-inflammatory drugs } \\
\text { Nodules; Non-steroidal anti- } \\
\text { inflammatory drugs only }\end{array}$ \\
\hline 6 & 70 & $\mathbf{F}$ & 2 & $1 / 256$ & 56 & $1 \cdot 6$ & $\begin{array}{l}\text { Generalised lymphadenopathy, } \\
\text { pernicious anaemia; salazopyrin, gold }\end{array}$ \\
\hline $\begin{array}{l}7 \\
8 \\
9\end{array}$ & $\begin{array}{l}60 \\
31 \\
53\end{array}$ & $\begin{array}{l}\mathbf{F} \\
\mathbf{F} \\
\mathbf{F}\end{array}$ & $\begin{array}{l}<1 \\
3 \\
3\end{array}$ & $\begin{array}{l}1 / 512 \\
1 / 128 \\
1 / 4096\end{array}$ & $\begin{array}{r}62 \\
32 \\
130\end{array}$ & $\begin{array}{l}2.6 \\
1.6 \\
0.8\end{array}$ & $\begin{array}{l}\text { Gold, melphalan, steroids } \\
\text { Non-steroidal anti-inflammatory drugs } \\
\text { Felty's syndrome, nodules }++ \text {; } \\
\text { gold }\end{array}$ \\
\hline $\begin{array}{l}10 \\
11 \\
12\end{array}$ & $\begin{array}{l}70 \\
72 \\
72\end{array}$ & $\begin{array}{l}F \\
F \\
M\end{array}$ & $\begin{array}{c}18 \\
4 \\
<1\end{array}$ & $\begin{array}{l}\text { Negative } \\
1 / 40 \\
\text { Negative }\end{array}$ & $\begin{array}{l}54 \\
41 \\
76\end{array}$ & $\begin{array}{l}0.7 \\
1.8 \\
1.6\end{array}$ & $\begin{array}{l}\text { Non-steroidal anti-inflammatory drugs } \\
\text { Disease quiescent at time of biopsy } \\
\text { Weight loss, long standing asthma; } \\
\text { Non-steroidal anti-inflammatory drugs } \\
\text { only }\end{array}$ \\
\hline 13 & 82 & F & 1.5 & Negative & 47 & $0 \cdot 6 / 0 \cdot 5$ & $\begin{array}{l}\text { Generalised lymphadenopathy; } \\
\text { ACTH, azathioprine }\end{array}$ \\
\hline 14 & 71 & F & 6 & $1 / 64$ & 126 & 0.9 & Vasculitis; gold, steroids \\
\hline
\end{tabular}

presence of Russell bodies. The predominant cell type in germinal centres (centroblast/centrocyte or mixed) was recorded. The following features were assessed semiquantitatively and scored $(-,+,++,+++$ ) (where - is absence of a feature and +++ is abundant expression): mitotic figures within germinal centres; numbers of tingible body macrophages; prominence of plasma cells (if multinucleate plasma cells were present this was noted); numbers of polymorphs in lymph node sinuses; and stainable iron and its distribution.

\section{MORPHOMETRY}

This was carried out using an IBM PC AT computer with Lietz Imagan II software, a Leitz Labolux microscope, and a Hitachi colour video camera linked to a television monitor. The proportion of the total lymph node cross sectional area (excluding large sinuses) occupied by secondary lymphoid follicles was measured. Form factors and maximum diameters of 20 adjacent germinal centres were also measured in each node. The same system was also used for quantifying cells in immunohistochemical sections.

\section{IMMUNOHISTOCHEMISTRY}

Cryostat sections $5 \mu \mathrm{m}$ thick were cut and stained in pairs of diseased and control nodes using a standard two stage immunoperoxidase technique with diaminobenzidine as substrate, as described elsewhere, ${ }^{10}$ and a panel of monoclonal antibodies (table 2). Using the Imagan system (which allows individual counted cells to be identified and marked on the video monitor screen) positive suppressor/cytotoxic $T$ cells (CD8 positive) using the antibody B941 and non-staining small lymphoid cells were counted in the paracortex to a total count of at least 1000 cells for each section. Helper/ inducer cells (CD4 positive) positive for Leu $3 a$ $+3 b$ were counted in the same way. Total numbers of IL2 receptor staining cells were counted per 10 high power video monitor fields and the counts converted into counts per $\mathrm{mm}^{2}$.

The areas of 10 random germinal centres were measured for each node and total numbers of CD8 positive $T$ cells counted in each and expressed as counts per $\mathrm{mm}^{2}$ of germinal centre. Counts of IL2R positive and CD4 positive cells were determined for five germinal centres in each node in the same way. The numbers of positively staining cells as a proportion of total individually identifiable lymphocytes in the lymphocyte coronas of five germinal centres were also counted in sections stained for IgA and $\kappa$ III. The total area of each frozen section was measured and the total number of CD1 positive cells counted and expressed as cells per $\mathrm{mm}^{2}$ of node cross section. Due to a shortage of frozen tissue every node could not be stained with the full panel of antibodies. All sections were read by one observer (GMK).

The data were statistically analysed by the Mann-Whitney $U$ test, except for germinal centre diameters and form factors for which Student's $t$ test was used.

\section{Results}

\section{HISTOLOGY}

The nodes from patients with rheumatoid arthritis ranged in maximum diameter from $0.5 \mathrm{~cm}$ to $2.6 \mathrm{~cm}$ (mean $1.3 \mathrm{~cm}$ ); those of controls $1.0-1 \cdot 7 \mathrm{~cm}$ (mean $1.3 \mathrm{~cm}$ ). Fibrous capsular thickening was present in three nodes from controls and one from a patient with rheumatoid arthritis.

Table 2 Antibodies used

\begin{tabular}{lll}
\hline Antibody & Specificity & Source \\
\hline IL2R & Interleukin 2 receptor (CD25) & Becton-Dickinson \\
Leu 3a+3b & Helper/inducer T cells (CD4) & Becton-Dickinson \\
B 941 & Suppressor/cytotoxic T cells (CD8) & Professor A J McMichael Oxford University \\
NA 134 & Interdigitating cells, Langerhans cells, thymocytes (CD1) & Professor A JcMichael Oxford University \\
DA 6231 & HLA-DR & Professor M Steel Edinburgh University \\
8a4 & $\gamma$ chain & Oxoid Unipath \\
2D7 & $\alpha$ chain & Oxoid Unipath \\
AF6 & $\mu$ chain & Oxoid Unipath \\
JA11 & $\delta$ chain & Oxoid Unipath \\
C7 & anti-V III & Dr R A Mageed Birmingham University \\
\hline
\end{tabular}


Figure 1 Rheumatoid lymph node (case 6) showing rounded, well separated follicles and extensive paracortex. (Haematoxylin and eosin.)

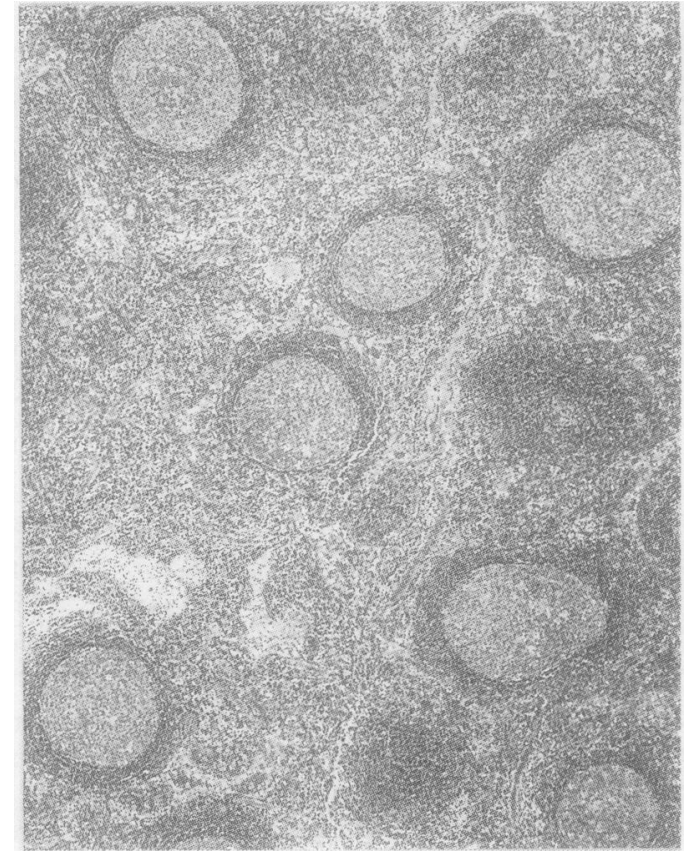

Germinal centres

Germinal centres extended into the medulla in all nodes apart from one diseased and one control node. Germinal centres were present in hilar fat in two diseased nodes, a feature not seen in the controls.

Generally the nodes from patients with rheumatoid arthritis contained a smaller area covered by germinal centres and their surrounding coronas (secondary follicles) as a proportion of nodal cross section-32.3\% (range $12 \%-41 \%)$; controls, $42 \%(12 \%-74 \%)-$ though this did not reach significance. Unlike three controls no node in the group with rheumatoid arthritis was more than $50 \%$ occupied by secondary follicles.

Fused germinal centres were present in eight $(50 \%)$ of the rheumatoid arthritis group and in six $(60 \%)$ of the controls. When present there were more fused and thus irregular germinal centres in the controls. The germinal centres in rheumatoid arthritis tended to be regular, rounded, and well separated (fig 1 ). The difference in form factors of germinal centres (a measure of roundness) between the two groups $0.87(\mathrm{SD} 0.10)$ and $0.85(0.11)$ was small and not significant. Germinal centres in rheumatoid arthritis were significantly smaller (mean diameter $504 \mu \mathrm{m}$ (range 146-2623 $\mu \mathrm{m})$ ); in controls the equivalent measurement was 710 $\mu \mathrm{m}$ (range 99-3651 $\mu \mathrm{m}(t=5.04, \mathrm{p}<0.005)$. Secondary follicles covered a greater proportional area in nodes from patients with high titre rheumatoid factor: $p<0.02$ (fig 2).

Mitotic figures were less common in the germinal centres of nodes from patients with rheumatoid arthritis, as were tingible body macrophages (table 3). Germinal centres with more mitotic figures tended to have more tingible body macrophages. When lymph nodes were divided according to the predominant cell type present in most germinal centres (centroblast/centrocyte/or mixed) there was a considerable difference between the two groups. Centrocytes tended to be the predominant follicle centre cells in the nodes from patients with rheumatoid arthritis, with centroblasts predominating in the control nodes (table 3 ). One node from the rheumatoid arthritis group (case 14) contained "burnt out" germinal centres without recognisable follicle centre cells. Thus features usually associated with very active germinal centres-high mitotic activity, numerous tingible body, macrophages, and a predominance of centroblasts-were relatively poorly represented in the nodes in rheumatoid arthritis (fig 3).

Occasional plasma cells were noted in the germinal centres of four $(25 \%)$ rheumatoid nodes and three $(30 \%)$ control nodes, though they were generally more obvious in the rheumatoid nodes. Russell bodies were present in the germinal centres of two rheumatoid nodes and one control.

Paracortex, medulla, and sinuses

Both rheumatoid and control nodes contained a well defined paracortex characterised by high endothelial venules which merged with a less well defined medulla. The paracortex generally seemed to be more prominent in the rheumatoid nodes and this probably contributed to the smaller proportional area occupied by secondary follicles. One rheumatoid node (case 14) was almost completely occupied by paracortex. There were no obvious differences in the numbers and arrangement of high endothelial venules between the two groups.

Plasma cells and particularly Russell bodies were more numerous in the paracortex and medulla of rheumatoid nodes (table 3 ). There was no correlation between these features and rheumatoid factor.

Sinuses were equally prominent in both groups, varying between being extremely dilated and inconspicuous. Sinus histiocytes were the most common cell type in both groups and were often admixed with polymorphs and small lymphocytes. Polymorphs were generally more plentiful in the group with rheumatoid arthritis (table 3). Phagocytosis of probably neutrophil derived nuclear debris forming clumps within sinus histiocytes was seen in two rheumatoid nodes (cases 1 and 6). In case 6 polymorphs also spilled out into the paracortex

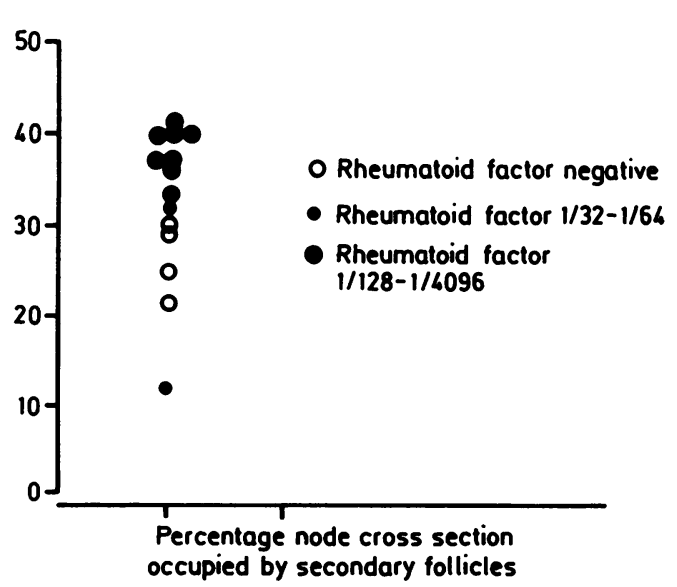

Figure 2 Relation of node cross section occupied by follicles to rheumatoid factor state. 
Table 3 Morphological features of rheumatoid and control lymph nodes

\begin{tabular}{|c|c|c|c|c|c|c|c|}
\hline \multirow[b]{2}{*}{$\begin{array}{l}\text { Patients with } \\
\text { rheumatoid } \\
\text { arthritis }\end{array}$} & \multirow[b]{2}{*}{$\begin{array}{l}\text { Predominant follicle } \\
\text { centre cells }\end{array}$} & \multicolumn{2}{|l|}{ Germinal centres } & \multicolumn{2}{|c|}{ Paracortex and medulla } & \multicolumn{2}{|c|}{ Paracortex and sinues } \\
\hline & & Mitotic figures & $\begin{array}{l}\text { Tingible body } \\
\text { Macrophages }\end{array}$ & Plasma cells & Russell bodies & $\begin{array}{l}\text { Polymorpho- } \\
\text { nuclear } \\
\text { leucocytes }\end{array}$ & $\begin{array}{l}\text { Stainable } \\
\text { iron }\end{array}$ \\
\hline $1^{*}$ & Centrocytes/centrocytes & $\begin{array}{l}+1+++ \\
++\end{array}$ & $\begin{array}{l}+1+ \\
++\end{array}$ & $\begin{array}{l}+1++ \\
++\end{array}$ & $+1++$ & $+1++$ & $++1++$ \\
\hline $\begin{array}{l}2 \\
3\end{array}$ & $\begin{array}{l}\text { Mixed } \\
\text { Centrocytes }\end{array}$ & $\begin{array}{l}++ \\
++\end{array}$ & $\begin{array}{l}++ \\
++\end{array}$ & $\begin{array}{l}++ \\
++\end{array}$ & $\stackrel{+}{+}+$ & $\stackrel{t}{++t}$ & ++ \\
\hline $\begin{array}{l}3 \\
4\end{array}$ & Centrocytes & $\begin{array}{l}++ \\
++\end{array}$ & $\begin{array}{l}++ \\
++\end{array}$ & +++ & $\begin{array}{l}++ \\
+\end{array}$ & $\begin{array}{l}+++ \\
+\end{array}$ & $t_{+t+}-e^{2}$ \\
\hline $\begin{array}{l}4 \\
5\end{array}$ & Centrocytes & $\begin{array}{l}++ \\
++\end{array}$ & + & + & $\begin{array}{l}+ \\
+\end{array}$ & & $\begin{array}{l}+++ \\
+\end{array}$ \\
\hline $\begin{array}{l}5 \\
6\end{array}$ & $\begin{array}{l}\text { Mixed } \\
\text { Centrocytes }\end{array}$ & $\begin{array}{l}++ \\
++\end{array}$ & + & +++ & $\begin{array}{l}+ \\
+\end{array}$ & $\stackrel{+}{+}++$ & ++ \\
\hline $\begin{array}{l}6 \\
7\end{array}$ & $\begin{array}{l}\text { Centrocytes } \\
\text { Centroblasts }\end{array}$ & $\begin{array}{l}t+1 \\
+t\end{array}$ & + & + & - & + & - \\
\hline 8 & Mixed & ++ & + & + & - & - & + \\
\hline 9 & Mixed & ++ & + & + & ++ & ++ & $\bar{z}$ \\
\hline 10 & Mixed & + & + & ++ & \pm & $\stackrel{+}{+}+$ & \pm \\
\hline 11 & Centrocytes & + & + & $\begin{array}{l}+ \\
++\end{array}$ & $\bar{t}$ & $\begin{array}{l}+t \\
++\end{array}$ & ++ \\
\hline 12 & $\begin{array}{l}\text { Centrocytes } \\
\text { Centroblasts/centrocytes }\end{array}$ & $\begin{array}{l}+ \\
+1-\end{array}$ & $\begin{array}{l}+ \\
+1+\end{array}$ & $\begin{array}{l}++ \\
+1+\end{array}$ & $-1-$ & $+1+$ & $-1-$ \\
\hline 14 & $\begin{array}{l}\text { Centrobblasts/centrocytes } \\
\text { Hypocellular }\end{array}$ & - & - & + & + & & + \\
\hline \multicolumn{8}{|l|}{ Controls } \\
\hline & Centroblasts & $\begin{array}{ll}+++ \\
++t\end{array}$ & $\begin{array}{l}+++ \\
++t\end{array}$ & $\stackrel{+}{+}+$ & $\stackrel{+}{+}$ & $\begin{array}{l}++ \\
++\end{array}$ & $\begin{array}{l}+ \\
+\end{array}$ \\
\hline $\begin{array}{l}2 \\
3\end{array}$ & $\begin{array}{l}\text { Centroblasts } \\
\text { Centroblats }\end{array}$ & $\begin{array}{l}+++ \\
+++\end{array}$ & $\begin{array}{l}++t \\
++\end{array}$ & - & - & - & $\begin{array}{l}+ \\
-\end{array}$ \\
\hline 4 & $\begin{array}{l}\text { Centroblasts } \\
\text { Mixed }\end{array}$ & $\begin{array}{l}++4 \\
++\end{array}$ & +++ & + & - & + & + \\
\hline 5 & Centroblasts & ++ & +++ & + & - & $\vec{t}$ & $\bar{t}$ \\
\hline 6 & Centroblasts & ++ & $\begin{array}{l}++ \\
++\end{array}$ & $\begin{array}{l}+ \\
+\end{array}$ & - & - & - \\
\hline $\begin{array}{l}7 \\
8\end{array}$ & Centroblasts & $\begin{array}{l}++ \\
+\end{array}$ & $\begin{array}{l}++ \\
+\end{array}$ & + & - & + & + \\
\hline $\begin{array}{l}8 \\
9\end{array}$ & $\begin{array}{l}\text { Centroblasts } \\
\text { Centrocytes }\end{array}$ & + & - & + & - & + & $\bar{z}$ \\
\hline 10 & Centroctyes & - & - & + & - & - & + \\
\hline
\end{tabular}

^Patients with two lymph node biopsy specimens.

in appreciable numbers. The two lymph nodes containing most polymorphs were from patients with high erythrocyte sedimentation rates. The lymph nodes from the two patients with the lowest erythrocyte sedimentation rates contained scarcely any polymorphs. Rheumatoid nodes generally contained more stainable iron (table 3).

The distribution of staining was similar, being present mainly in sinuses with occasional paracortical and germinal centre staining. Three $(19 \%)$ of the rheumatoid nodes showed striking encrustation of haemosiderin around germinal centre capillaries, a feature not seen in those of controls. Iron staining showed no obvious relation to clinical features. Melanin was present in both nodes from case 1 and two other rheumatoid nodes (cases 3 and 12). Small amounts of anthracotic type pigment were present in three rheumatoid and one control node.

\section{IMMUNOHISTOCHEMISTRY}

Light chain staining showed a polytypic pattern in all nodes. Staining for IgM, IgG, IgA and IgD produced the same overall pattern in both groups. Lymphoctye coronas and germinal centres stained for $\operatorname{IgM}$, coronas alone for IgD, and follicle centres for IgG. IgA staining was shown on a proportion of coronal lymphocytes and produced weak germinal centre staining. There was a difference in the intensity of staining which was difficult to quantify, with generally stronger follicle centre
Figure 3 Typical germinal centre in (case 5). Tingible body macrophages and mitotic figures are inconspicuous. Most of the follicle centre cells are centrocytes. (Haematoxylin and eosin.)

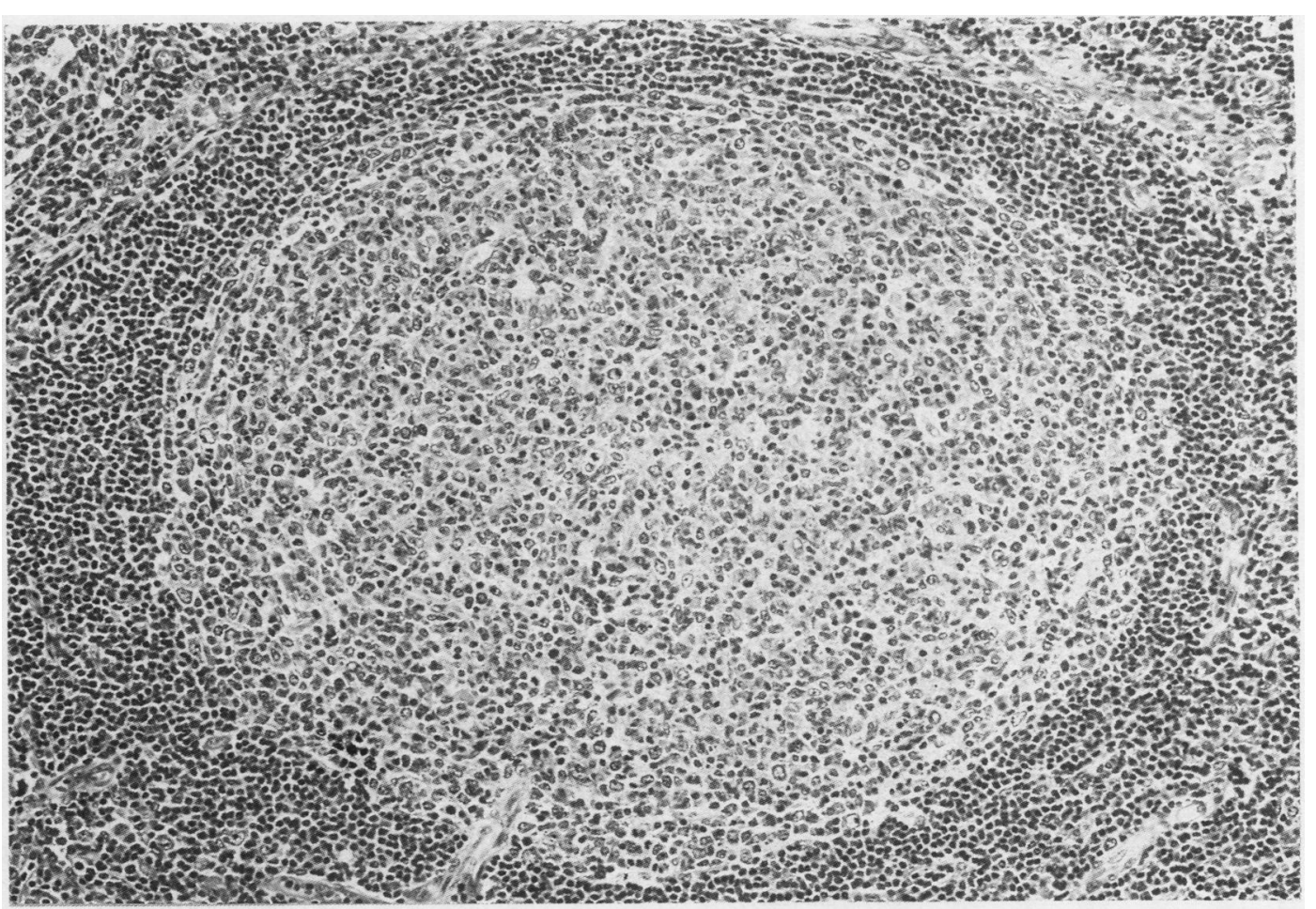


Figure 4 Kappa III staining coronal lymphocytes in rheumatoid arthritis (case 13). (Immunoperoxidase.)

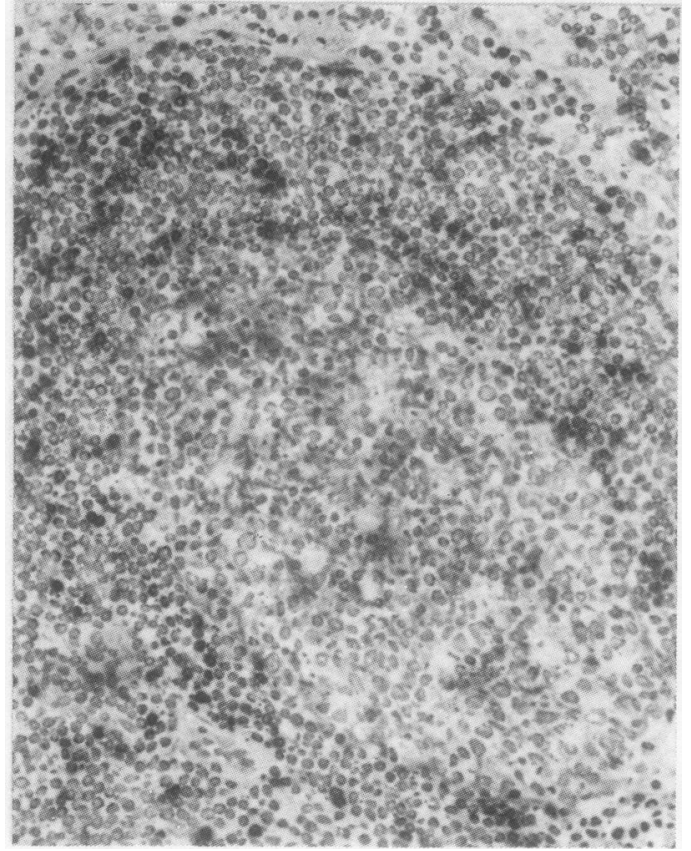

staining for IgG and IgA, and to a lesser extent, $\operatorname{IgM}$ in the group with rheumatoid arthritis. Occasional groups of paracortical cells with macrophage morphology also stained for IgG, $\operatorname{IgA}$, and IgM and this again seemed to be rather stronger (especially IgA) in the group with rheumatoid arthritis.

IgA positive lymphocytes were more common in rheumatoid follicle coronas as a proportion of coronal cells $(n=7)$ mean $3.91 \%$ (range 1.0-5.4\%); controls $(n=7)$ mean $1.67 \%$ (range $1 \cdot 0-4 \cdot 7 \%$ ), though this was not significant.

Cells staining for $\kappa$ III were also more common in the lymphocyte coronas (fig 4) of nodes $(n=7)$, mean $33 \%$ (range $25 \%-44 \%$ ); controls $(n=7)$, mean 25\%, (range 8-29\%) $\mathrm{p}<0.05$, but this did not correlate with rheumatoid factor.

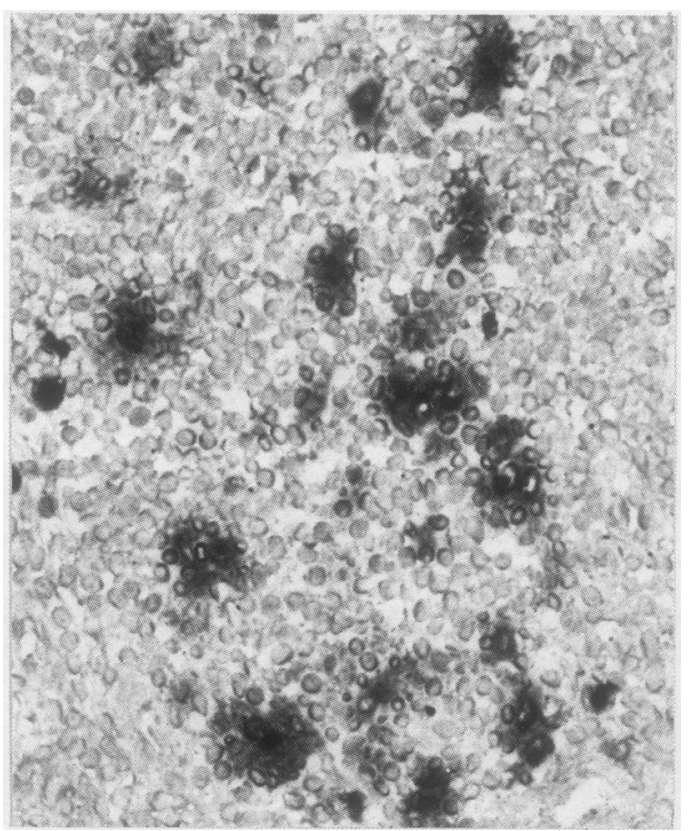

Figure 5 Aggregates of interdigitating cells in paracortex of rheumatoid node (case 13). Many seem to be intimately associated with small lymphocytes. (Immunoperoxidase.)
Staining for class II histocompatibility antigens (HLA DR) showed strong staining of many paracortical and follicular cells with no obvious difference between the groups. Staining for interdigitating cells (CD1 positive) showed aggregates of large cells with plentiful cytoplasm in the paracortex of both groups which often seemed to be intimately associated with small lymphocytes (fig 5). These were more numerous in the group with rheumatoid arthritis $(n=7)$, mean $7 \cdot 0$ (range $2 \cdot 2-11 \cdot 6)$ per $\mathrm{mm}^{2}$; controls $(\mathrm{n}=8)$, mean $4 \cdot 6$ (range $0 \cdot 4-7 \cdot 3$ ) per $\mathrm{mm}^{2}(\mathrm{p}>0.05)$. The mean paracortical CD4 + : CD8 + cell ratio for the rheumatoid arthritis group was slightly higher: $2 \cdot 2(n=9)$ (range 1.0-2.7); controls $(n=10)$, mean 1.8 (range $0 \cdot 8-2 \cdot 7$ ). This was not significant.

There was a striking infiltration of rheumatoid germinal centres by CD8 positive cells $(\mathrm{n}=8)$, mean 165 (range 52-441) per $\mathrm{mm}^{2}$. They were usually scarce in control germinal centres $(n=10)$, mean 55 (range 7-209) per $\mathrm{mm}^{2}$ (figs 6-8) $(\mathrm{p}<0.05)$.

$T$ helper/inducer (CD4 positive) cells were present in larger numbers in the germinal centres of both groups: rheumatoid arthritis $(\mathrm{n}=8)$, mean 820 (range 300-1520) per $\mathrm{mm}^{2}$; controls $(n=10)$, mean 1000 (range 140-1850) per $\mathrm{mm}^{2}$ with no significant difference between the groups. Estimated CD4 +: CD8 + cell ratios on the basis of these results ranged from 3.4-11.4 (mean 6.96) in rheumatoid arthritis $(n=8)$, and 5.4-112.8 (mean 32.2) in controls $(n=10), p<0.05$.

IL2 receptor staining in the paracortex and germinal centres was mainly seen in small and medium sized lymphoid cells. There were generally fewer positive cells in the paracortex of the rheumatoid arthritis group $(n=8)$, mean 3230 (range 2620-4240) per $\mathrm{mm}^{2}$; controls $(\mathrm{n}=8)$, mean 4130 (range $2750-4960)$ per $\mathrm{mm}^{2}$, $p<0.02$. Low numbers of IL2R positive paracortical cells tended to be associated with

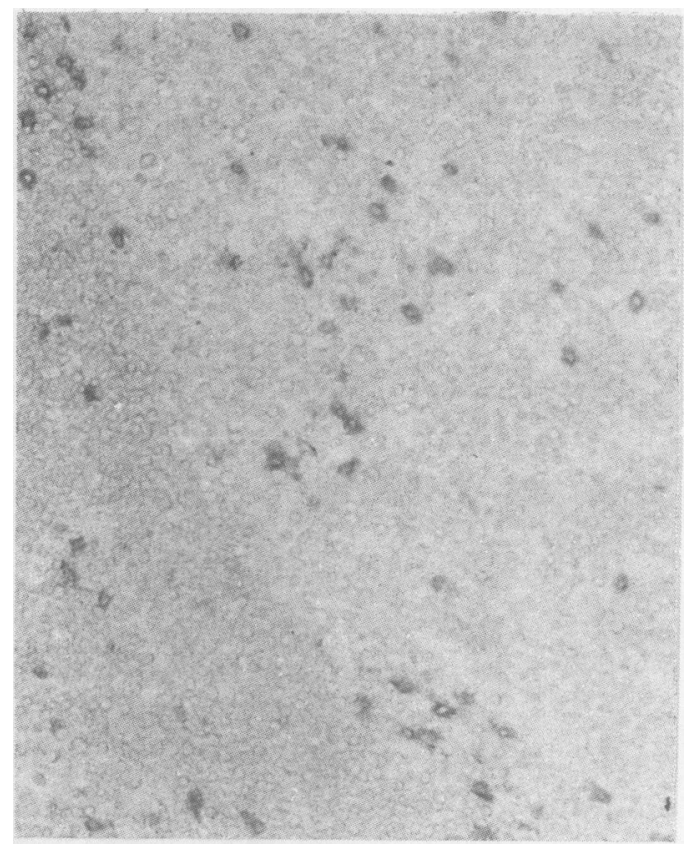

Figure 6 Germinal centre in case 11 with rheumatoid arthritis, showing infiltration by CD8 positive T cells. (Immunoperoxidase.) 
Figure 7 Control node with follicular hyperplasia. Note very sparse CD8 positive T cells within germinal centre.

(Immunoperoxidase.)

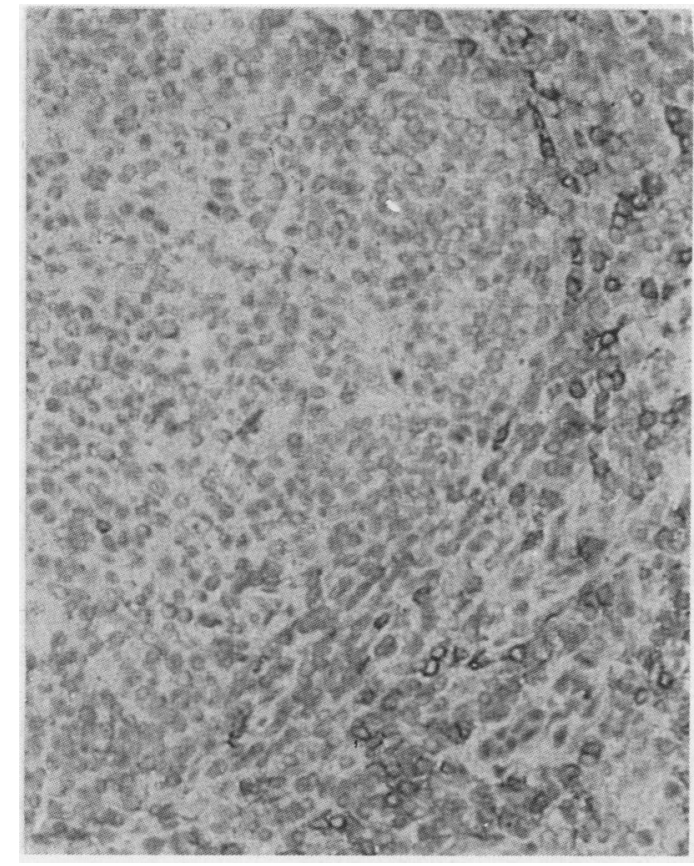

high disease activity as reflected by the erythrocyte sedimentation rates, though in one patient with an erythrocyte sedimentation rate of 10 there were low numbers.

In germinal centres IL2R positive cells were rather more numerous in the rheumatoid arthritis group-mean 82.5 (range 33.3-211.4) per $\mathrm{mm}^{2}$; controls, 59.6 (range 14.3-164.2) per $\mathrm{mm}^{2}$. This did not reach significance. By far the largest number of positive cells in the control group was in the patient with possible AIDS.

There did not seem to be any correlation between numbers of positive cells in the germinal centres and paracortex in the control group, but a closer relation in the rheumatoid arthritis group (fig 9).

\section{Discussion}

The rheumatoid nodes showed histological features in keeping with those described in earlier studies of, in particular, follicular hyperplasia, ${ }^{1-25-8}$ although one node (case 6) from a patient with vasculitic manifestations contained small "burnt out" follicles and an extremely expanded paracortex.

Compared with the control group the degree

Figure 8 Suppressor/ cytotoxic cell (CD8 positive) numbers in germinal centres of patients with rheumatoid arthritis and control groups.

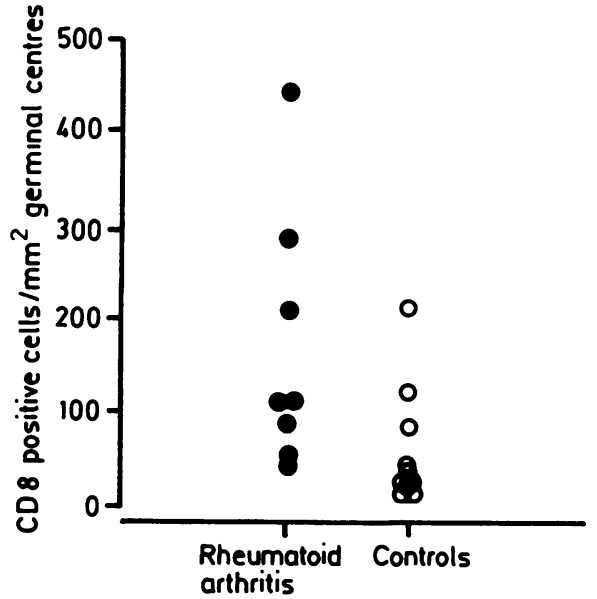

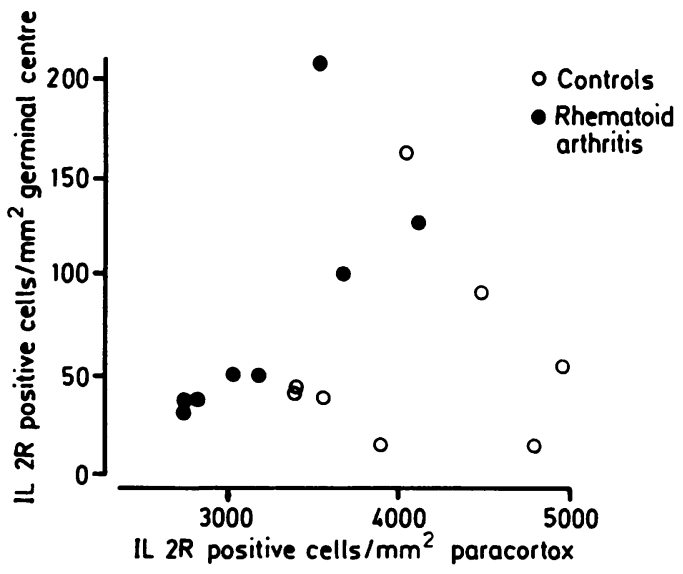

Figure 9 Scattergram showing relation between numbers of germinal centre and paracortical IL $2 R$ positive cells. There is a good correlation in group with rheumatoid arthritis $r=0.72$ but not in the control group, $r=0.05$.

of follicular hyperplasia in terms of the size of germinal centres and the proportion of nodal area occupied by them was lesser in the group with rheumatoid arthritis. Germinal centres in rheumatoid lymph nodes also tended to be rounder, less irregular in shape, and well separated from each other. Simple indicators of proliferative activity such as numbers of mitotic figures, tingible body macrophages, and prominence of centroblasts all pointed to the germinal centres being relatively less active in the rheumatoid nodes. This is at variance with several previous accounts (which did not use control cases), which mention the prevalence of tingible body macrophages in rheumatoid arthritis lymphadenopathy. ${ }^{128}$ These characteristics may have contributed to the occasional misdiagnosis of follicular lymphoma noted because rounded germinal centres containing sparse mitotic figures, few tingible body macrophages, and a preponderance of centrocytes are features associated with follicular lymphoma. ${ }^{10}$

It can be argued that a control group with follicular hyperplasia, presumably due in most cases to self-limiting viral infections, would contain a high proportion of young patients and that this would underplay the activity of germinal centres in rheumatoid arthritis as young patients, particularly children, often have striking follicular hyperplasia. ${ }^{12}$ Only one very young patient, in the control group, however, the youngest patient in the group with rheumatoid arthritis ( 31 years), and the oldest in the control group (53 years) had appearances typical of their own groups. Thus the age differences between the two groups may not have accounted for the apparent inactivity of the rheumatoid arthritis follicles. A factor which may have had a bearing on germinal centre activity was the duration of lymphadenopathy but this clinical information was not available.

Many of the rheumatoid nodes had a prominent paracortex which may have contributed to the relatively small proportion of the node occupied by secondary follicles.

Evidence that lymph node follicles are involved at some stage in the generation of rheumatoid factor producing cells is provided 
by the correlation between area occupied by follicles and rheumatoid factor (fig 2).

In the group with rheumatoid arthritis there were appreciable numbers of plasma cells and Russell bodies. Although one previous account states that Russell bodies are rare, ${ }^{6}$ they were found in most rheumatoid nodes and may be useful in the diagnosis of rheumatoid arthritis lymphadenopathy. Rather surprisingly these features did not show any association with seropositivity for rheumatoid factor.

Polymorphs were common in rheumatoid nodes but were also often seen in the control group. These findings do not support the contention that this is a particularly characteristic feature. ${ }^{7}$ The results did, however, suggest that polymorphs may be more numerous in active disease.

Haemosiderin was present in most rheumatoid nodes, generally in greater amounts than in controls. Some of these patients had been given blood transfusions in the past, although increased haemosiderin deposition in the nodes of untransfused patients has been reported. ${ }^{13}$ In the patients studied there seemed to be no association with disease activity or rheumatoid factor secretion. In common with other studies amyloid deposition and vasculitis were not seen.

Staining for immunoglobulin heavy and light chains was generally stronger in the group with rheumatoid arthritis where, in addition to staining of B lymphocytes, there was often a prominent reticular staining of germinal centres and scattered histiocyte-like cells in the paracortex. This may be a reflection of passive absorption of immunoglobulins in a disease in which some degree of hypergammaglobulinaemia is common, but it is also possible that immunoglobulins are being localised by antigen presenting cells. The local production of rheumatoid factors by nodes affected by rheumatoid arthritis is supported by the fact that a higher proportion of coronal lymphocytes were stained by the antibody to $\kappa$ III, which stains a $\kappa$ chain epitope particularly associated with autoantibody production. ${ }^{14}$ Some staining was also seen in all control nodes. Interdigitating cells were more numerous in the rheumatoid nodes which may again be a manifestation of active antigen presentation. These cells were often intimately associated with small lymphocytes.

A recent morphometric study comparing rheumatoid and osteoarthritic synovium confirmed the presence of a high CD4 $+: \mathrm{CD} 8+\mathrm{T}$ cell ratio in lymphoid aggregates in rheumatoid synovium (mean ratio $3 \cdot 8: 1$ ). ${ }^{15}$ This was not, however, constant in all areas of the synovium with a ratio of only $0 \cdot 6: 1$ away from the aggregates. The CD4 + : CD8 + cell ratios in the lymph node paracortex of the rheumatoid arthritis and control groups were both close to 2.0 . This is rather lower than that noted in lymph nodes and tonsils in other studies which ranged from about $2 \cdot 5-4 \cdot 0 .{ }^{16-19}$ Interestingly, the patient with rheumatoid arthritis (case 14) with a vasculitic illness and a highly expanded paracortex had a very low ratio of $1 \cdot 0$. The $\mathrm{CD} 4+: \mathrm{CD} 8+$ cell ratio in this study is an estimate as it was not possible to carry out double labelling techniques.

A striking feature of the rheumatoid nodes was the approximately threefold greater concentration of CD8 positive lymphocytes in germinal centres compared with those of controls. CD8 positive lymphocytes were generally scarce in germinal centres in contrast to $\mathrm{CD} 4$ positive $\mathrm{T}$ lymphocytes. This observation may throw some light on the apparent proliferative inactivity of the germinal centres in rheumatoid arthritis as the CD8 positive lymphocytes may be damping down germinal centre expansion locally. The numbers of CD8 positive cells in germinal centres did not, however, show any obvious relation to simple morphological indicators of proliferation in either the rheumatoid arthritis or control groups. CD8 positive $T$ cells have been reported as being more common in the germinal centres of patients with AIDS, ${ }^{20}$ and our patient who may have had AIDS showed increased numbers. As numbers of CD4 positive cells in the germinal centres of both groups were similar the estimated CD4 + : CD8 + cell ratios were generally much lower in germinal centres in rheumatoid arthritis. There were too few nodes available to show a significant correlation with disease activity and rheumatoid factor production but there may be a relation as the three cases with erythrocyte sedimentation rates above $50 \mathrm{~mm} /$ hour and rheumatoid factor titres of $1 / 256$ or over had lower than average CD8 positive cell numbers and higher than average ratios.

The lymphokine IL-2 has an important role in the regulation of the immune system and the receptor for IL2 is expressed on activated T cells. It has been suggested that there are abnormalities of IL2 biology in rheumatoid arthritis with deficient IL2 production by peripheral blood lymphocytes in vitro, though numbers of activated lymphocytes and IL2 receptor expression are increased. ${ }^{21}$ Addition of recombinant IL2 to cell cultures has also been reported to reverse a deficiency of activated CD8 positive and leu-7 positive (natural killer) cells in lymphocytes from peripheral blood in rheumatoid arthritis. ${ }^{22}$ Large amounts of IL2 and IL2 receptor mRNA transcripts have, however, been found in synovial membrane and fluid cells. ${ }^{23}$ In this study counts of interleukin 2 receptor positive cells in the paracortex were significantly lower in the rheumatoid arthritis group than in the controls. This does not mean that the rheumatoid paracortex is inactive as the control nodes are probably highly activated. A possible explanation may be that activated lymphocytes migrate out of the paracortex into synovium in active disease leaving the node partly depleted. It has been shown that patients with active synovitis have raised numbers of circulating activated lymphocytes. ${ }^{24}$ Fewer IL2R positive paracortical cells were present in the patients with higher erythrocyte sedimentation rates, although one patient with a normal erythrocyte sedimentation rate also had low numbers. It is not possible to exclude the effects of treatment as most patients with active disease were 
receiving second line drugs including steroids. IL2R positive cell numbers were similar in the germinal centres of the control and rheumatoid arthritis groups. Interestingly, there seems to be a correlation between IL2R positive cell numbers between the paracortex and germinal centres only in the rheumatoid arthritis group (fig 9). The lack of any correlation in the control group is probably a reflection of the heterogenous nature of this group. Conversely, although it did not quite reach significance, this relation suggests a "family resemblance" in the rheumatoid arthritis group also apparent in other histological and immunohistochemical features. This circumstantial evidence contradicts the suggestion that rheumatoid arthritis may be a group of diseases rather than a homogenous disease. ${ }^{25}$

We are grateful to the Medical Research Endowment Fund, Central Birmingham Health Authority, Birmingham for financial support and Drs D M Goodall, G Brown, and R Jefferis of the Department of Immunology, University of Birmingham for help and advice. We also thank Mr J Gregory and Mrs J Fitzmaurice for technical assistance and Miss A J Wright for typing the manuscript.

1 Nosanchuk JS, Schnitzer B. Follicular hyperplasia in lymph nodes from patients with rheumatoid arthritis. Cancer nodes from patient

2 Cruikshank B. Lesions of lymph nodes in rheumatoid disease and in disseminated lupus erythematosus. Scot Med J 1958;3:110-9.

3 Lea AJ. An association between the rheumatic diseases and the reticuloses. Ann Rheum Dis 1964;23:480-4

4 Symmons DPM, Ahern M, Bacon PA, et al. Lymphoproliferative malignancy in rheumatoid arthritis a study of 20 cases. Ann Rheum Dis 1984;43:132-5.

5 Motulsky AG, Weinberg S, Saphir O, Rosenberg E. Lymph nodes in rheumatoid arthritis. Arch Intern Med 1952; 90:660-76.

6 Gardner DL. Pathology of connective tissue diseases. London: Edward Arnold, 1965:93-5.

7 Fassbender HG. Pathology of rheumatic diseases. New York: Springer-Verlag, 1975:186-8.

8 Kelly CA, Malcolm AJ, Griffiths I. Lymphadenopathy in rheumatic patients. Ann Rheum Dis 1987;46:224-7.
9 Committee of the American Rheumatism Association. 1958 Revision of diagnostic criteria for rheumatoid arthritis. Revision of diagnostic criteria

10 Mason DY, Naiem M, Abdulaziz Z, Nash JRG, Gatter KC Stein $\mathrm{H}$. Immunohistochemical labelling of cryostat sections with monoclonal antibody. In: McMichael AJ, Fabre JW, eds. Monoclonal antibodies in clinical medicine. London: Academic Press, 1984:632-5.

11 Wright DH, Isaacson PG. Biopsy pathology of the lymphoreticular system. Baltimore: Williams and Wilkins, 1983: $171-4$.

12 Stansfeld AG. Lymph node biopsy interpretation. Edinburgh: Churchill Livingstone, 1985:91.

13 Muirden KD. Lymph node iron in rheumatoid arthritis. Histology, ultrastructure and chemical concentration. Histology, ultrastructure and

14 Mageed RA, Walker MR, Jeffers R. Restricted light chain subgroup expression on human rheumatoid factor paraproteins determined by monoclonal antibodies. Immun ology 1986;59:473-8.

15 Kennedy TD, Plater-Zyberk C, Partridge TA, Woodrow DF, Maini RN. Morphometric comparison of synovium from patients with osteoarthritis and rheumatoid arthritis. $J$ Clin Pathol 1988;41:847-52.

16 Janossy G, Tidman N, Warwick S, et al. Human $T$ lymphocytes of inducer and suppressor type occupy lymphocytes of inducer and suppressor type occupy

17 Dvoretsky P, Wood GS, Levy R, Warke RA. T-lymphocyte subsets in follicular lymphomas compared with those in non-neoplastic lymph nodes and tonsils. Hum Pathol non-neoplastic

18 Modlin RL, Meyer PR, Hofman FM, et al. T-lymphocyte subsets in lymph nodes from homosexual men. JAMA 1983;250:1302-5.

19 Wood GS, Burns BF, Dorfman RF, Warke RA. In situ quantitation of lymph node, helper, suppressor and cytotoxic T cell subsets in AIDS Blood 1986;67:596-603.

20 Said JW, Shintaku IP, Teitelbaum A, Chien K, Sassoon AF Distribution of $T$-cell phenotypic subsets and surface immunoglobulin bearing lymphocytes in lymph nodes from male homosexuals with persistent generalised lymfrom male homosexuals with persistent generalised lymphadenopathy: an immunohistochemical

21 Kitas GD, Salmon M, Farr M, Gaston JSH, Bacon PA. Deficient interleukin 2 production of rheumatoid arthritis: association with active disease and systemic complications. Clin Exp Immunol 1988;73:2142-249.

22 Salmon M, Bacon PA. A cellular deficiency in the rheumatoid one-way mixed lymphocyte reaction. Clin Exp Immunol 1988;71:79-84.

23 Buchan G, Barret K, Fujita T, et al. Detection of activated T cell products in the rheumatoid joint using CDNA probes to Interleukin-2 (IL-2) IL-2 receptor and IFN- - . Clin Exp Immunol 1988;71:295-301.

24 Papadimitriou GM, Bacon PA, Hall ND. Circulating activated lymphocytes in rheumatoid arthritis a marker of activated lymphocytes in rheumatoid arthritis a marker

25 McCusker CT, Singal DP. Molecular relationships between the class II HLA antigens and susceptibility to rheumatoid arthritis. Editorial, $J$ Rheumatol 1988; 15:1050-3. 